\title{
Estimation of Carbon Stock in Sungai Merah Protection Forest, Musi Banyuasin Regency of South Sumatra Province, Indonesia
}

\author{
Lulu Yuningsih ${ }^{1}$, Ifran D. Imanda ${ }^{2}$, Ayu Wulandari ${ }^{2}$, Delfi Lensari ${ }^{2}$, Jun Harbi ${ }^{2,3}$ \\ ${ }^{I}$ Doctoral Student of Environmental Management, Sriwijaya University, Indonesia \\ ${ }^{2}$ Forestry Department, Faculty of Agriculture, Muhammadiyah University of Palembang, South Sumatra, \\ Indonesia. \\ ${ }^{3}$ Forestry Economics and Management Department, Faculty of Economics and Management, Northeast Forestry \\ University, Harbin, China \\ *Corresponding Author: junharbi@gmail.com
}

Article history

\begin{tabular}{llll} 
Received & Received in revised form & Accepted & Available online \\
12 August 2020 & 15 December 2020 & 31 December 2020 & 31 December 2020 \\
\hline
\end{tabular}

\begin{abstract}
Calculation and estimation of carbon stocks in various types of forests and ecosystems in Indonesia has been widely practiced. However, the availability of carbon stock information for some locations in the remaining forest area in South Sumatra Province is still very limited. This study aim to measuring the carbon storage potential and the ratio between the carbon storage value derived from the interpretation of satellite imagery and the storage of carbon stock from the field calculation. The method used is to calculate the estimation of carbon stock through satellite imagery interpretation and field measurement. The largest estimation of carbon stock through satellite image interpretation was found in secondary forest cover type with yield of $896,234 \mathrm{ton} / \mathrm{c} / \mathrm{ha}$, followed by plantation land type with a yield of $147.104 \mathrm{ton} / \mathrm{c} / \mathrm{Ha}$ and the smallest is open land cover with value yield of 2.883 tons/c/ha. While carbon stocks through field measurement yield 429,181 ton/c/ha of secondary forest cover type, followed by plantation land with 41,169 ton/c/ha and 4,283 ton/c/ha for open land type. A comparison of carbon stock estimates of the two approaches used, yielding a reference value of $220 \%$. These comparative values can help carry out initial estimates of carbon stocks in some types of land cover especially for lowland forest types.
\end{abstract}

Keywords: Carbon stock, low land forest, protection forest, South Sumatra

\section{Introduction}

Global warming became one of the major environmental issues facing the world today. Global warming is associated with increasing greenhouse gas concentrations in carbon dioxide, methane, and nitrogen oxides in the atmosphere. The significant contribution resulting in the accumulation of these chemical gases is human activity, which results in the increasing average temperature on the earth's surface. The Burning of fossil fuels, the conversion of forests into another useful area, and forest fires are examples of rising earth surface temperatures that lead to climate change, extreme weather, and the changes in forests' ecological functions [1].

One form of the change in ecological functions of forests resulting from global warming is the decreasing ability of forest vegetation to absorb carbon through photosynthesis. Carbon sequestration is believed to be an effort to reduce and minimize the impact of disasters caused by global warming.

Carbon sequestration $\left(\mathrm{CO}_{2}\right)$ through the photosynthesis process by vegetation is done by storing the result of the process into organic material called carbon stored in the plant biomass. Human activities that disrupt the biomass storage of vegetation causes the release of carbon stored in biomass into the atmosphere, which triggers climate change, leading to an imbalance of energy between the earth and the atmosphere [2].

However, the ability to absorb and store carbon in each land cover differs from one to another. The researchers noted that carbon sequestration capabilities for natural forests, secondary forests, plantations, swamp forests, and community plantations are all affected by tree species, soil types, topography, and other supporting factors [3].

The calculation of carbon stocks in different types of forests and ecosystems has been practiced. However, the availability of carbon stock information in some locations, especially for the remaining forest area in South Sumatra Province, is still very limited. This research is conducted as one of the efforts to know the availability of carbon stock information in Sungai Merah Protection Forest KPHP Unit IV Meranti, Musi Banyuasin Regency, South Sumatra Province. This research aims to: counting the potential of carbon stocks and comparing the value of carbon stocks calculated by estimating satellite imagery and direct field measurement. 


\section{Material and Methods}

\subsection{Study area}

The research was conducted in Sungai Merah Protection Forest Unit of Production Forest Management (KPHP) Unit IV Meranti of Musi Banyuasin Regency, South Sumatra, Indonesia and Laboratory of BPK (Forest Research Agency) in Palembang. This study was conducted for three months, from May to August 2016 (Figure 1). We used Landsat 8 Path/Row 125-0623 satellite images of July 2014 coverage.

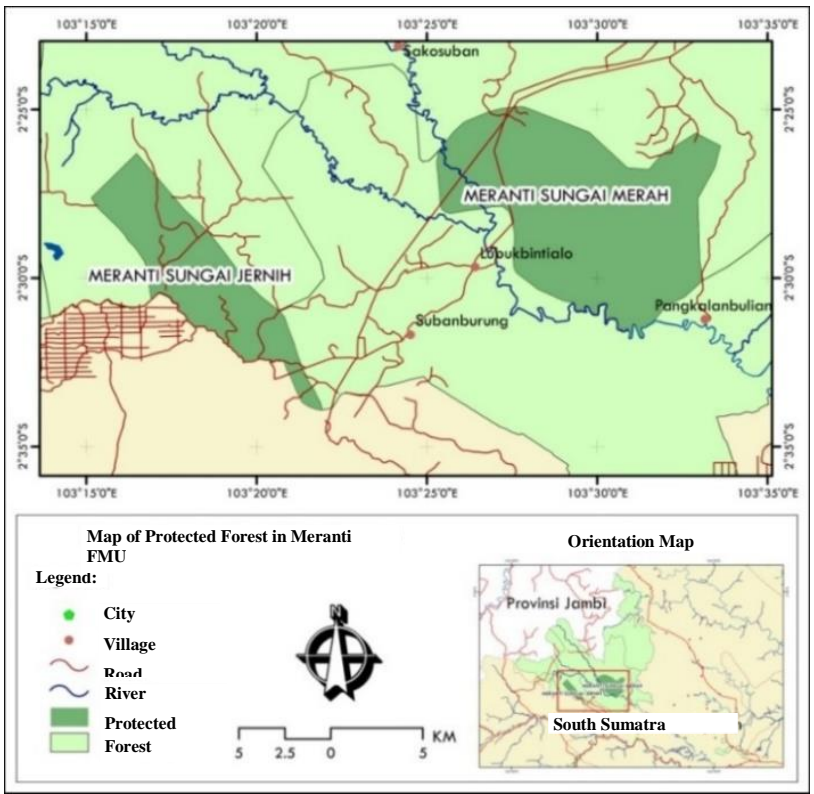

Figure 1. Map of Research Location

\subsection{Procedures}

The research procedure is carried out through the following stages, conduct the land cover analysis through Landsat satellite image interpretation, implement the carbon accounting above-ground biomass, determine the carbon's content, and data analysis.

\subsection{Data analysis}

The satellite imagery interpretation of the existing land cover in the Sungai Merah Protection Forest (SMPF) was implemented at the beginning of the study. Research conducted by [4] carried out the plot determination based on land cover known through analysis of the land cover image. The number of plots is stacked based on the existing standing density index on each land cover, so there will be a large, medium, and small plot at that location. The interpretation result is three types of land cover, consisting of secondary forest (6,895.70 ha), plantation (3,632.22 ha), and open land
(860.60 ha). The number of measurement plots for each land cover is not equal in number because it is adjusted to each land cover's extent.

The estimation of carbon stock is calculated by multiplicating each land cover area with a carbon constant value based on the land cover type. The general equation developed by [5] with the formula which is

Carbon land cover $=$ wide of land cover $\mathrm{x}$ Kc (1)

where:

$\mathrm{Kc}=$ Carbon constants (secondary forest $=129.97$; plantation $=40.5$; open land $=3.35$ ) .

Knowing the extent of land cover, this information helps determine the number of plots for each land cover. The number of identification plots based on land cover area is 28 plots, consisting of 17 plots for secondary forest area, 9 plots for plantation area, and 2 plots in the open area. Each plot has $20 \mathrm{~m} \times 20 \mathrm{~m}$ adapted to plot guides in the natural forest to measure trees, poles, bets, and plants.

The tree carbon biomass was measured using the general allometric equations developed by [6]. The formula is:

$$
\mathrm{Y}=0,118 \mathrm{D} 2,53 \text {. }
$$

Where:

$\mathrm{Y}=$ tree biomass (ton $/ \mathrm{ha}) ; \mathrm{D}=$ tree diameter $(\mathrm{cm})$.

Whereas the calculation of carbon using the formula:

$$
\mathrm{C}=\mathrm{Y} \times 0.5
$$

where $\mathrm{C}=$ Carbon (ton/c/ha); $\mathrm{Y}=$ Tree biomass (ton/ha); $0.5=$ Conversion factor for carbon estimates.

To estimate the calculation of down plants carbon, we are using the calculation equation based on the results of research [7] with the formula:

$$
B T B=\frac{B K C_{t b}}{B B C_{t b}} \times T B B_{t b}
$$

whereas for the measurement of litter carbon using the formula:

$$
B S S=\frac{B K C_{S S}}{B B C_{s S}} \times T B B_{S S}
$$

Where: $\mathrm{BTB}=$ young vegetation biomass; $\mathrm{BKCtb}=$ dry weight of the sample of young vegetation; $\mathrm{BBCtb}=$ the wet weight of the sample of young vegetation; $\mathrm{TBBtb}=$ the total wet weight of young vegetation; $\mathrm{BSS}=$ the litter of biomass above the soil surface; $\mathrm{BKCss}=$ the dry weight of the sample. 


\section{Results and Discussion}

\subsection{Estimation of carbon stock using the interpretation} of satellite imagery

Based on Forestry Minister's Decree No. 689 of 2012, KPHP unit IV Meranti is set with an area of 252,267 ha. The area consists of Protection Forest area of 20,081 ha $(7.96 \%)$, Limited Production Forest of 97,587 ha (38.68\%) and Production Forest with an area of about 134,599 ha $(53.36 \%)$. To identify the extent potential area around the research site, remote sensing and analysis are done using Landsat 8 Path/ Row 1250623 satellite images of July 2014 coverage. The study area's focus is to see the land cover in Sungai Merah Protected Forest area KPHP unit IV Meranti. The information generated from satellite imagery interpretation is three types of land cover, which are secondary forest (dark green), plantation (light green), and open land (pink) as in Figure 2.

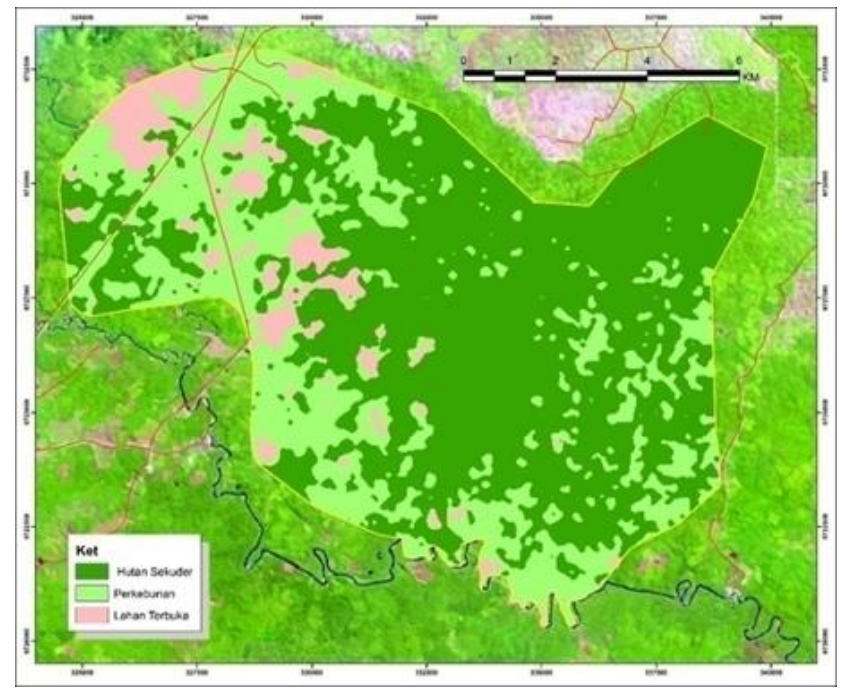

Figure 2. Interpretation of Satellite Image for Sungai Merah Protection Forest

The calculation of carbon stock estimation is obtained by multiple the wide area of each land cover in HLSM with general constants value. The results give information that the highest carbon stock value is found in the secondary forest cover of 896,234 ton/ $\mathrm{C} /$ ha, followed by the land cover of the plantation of 147,104 ton/c/ha and the lower is in the land cover of open land that is $2,883 \mathrm{ton} / \mathrm{c} / \mathrm{ha}$.

\subsection{Estimation of carbon stock using the interpretation of field measurement}

The estimation of carbon stocks through field measurement was conducted on 28 selected plots in each landcover type: secondary forest, plantations, and open land. There are three types of measured objects: the tree, young vegetation, and litter. The three objects were done by measuring the diameter. While the litter, the measurement was done by taking samples in the field, then doing the laboratory analysis to measure the wet weight and dry weight ratio of the litter sample.

The results of measurement and analysis of the highest estimation of carbon stock in the secondary forest of tree type were found in plot 14 with carbon estimation value of 12,185 ton $/ \mathrm{c} / \mathrm{ha}$, for young vegetation type found in plot 6 of 0.108 ton/c/ha while for litter was encountered on plot 8 of 74 ton/c/ha. To estimate the lowest carbon stocks in the secondary forest of the tree typically found in plot 7 with the estimated carbon value of $0.002 \mathrm{ton} / \mathrm{c} / \mathrm{ha}$, the plant type was encountered in plots 1 and 2 of 0.001 ton/c/ha and for litter type encountered in plot 7 of $0.007 \mathrm{ton} / \mathrm{c} / \mathrm{ha}$.

The measurements and analysis of the estimates of the highest carbon stocks in the plantations of tree species were found in plot 8 with a carbon estimation value of $1.409 \mathrm{ton} / \mathrm{c} / \mathrm{ha}$, and the young vegetation was found in plot 6 of $0.211 \mathrm{ton} / \mathrm{c} / \mathrm{ha}$ while the litter type was encountered in the plot 7 of 0.118 ton/c/ha. The estimates of the lowest carbon stocks in plantations for tree type are found in plot 8 with carbon estimation value $0.297 \mathrm{ton} / \mathrm{c} / \mathrm{ha}$, for young vegetation encountered in plot 4 of 0.121 ton/c/ha with and for litter type encountered in plot 9 of 0.033 ton/c/ha.

The measurement and analysis of the highest estimation of carbon stock in the open field of tree type were found in plot 1 with the estimated carbon value of $2.597 \mathrm{ton} / \mathrm{c} / \mathrm{ha}$, and young vegetation type was found in plot 1 of 0.287 ton/c/ha while the litter type was encountered on plot 1 of 0.242 ton/c/ha. The result of the estimation of the lowest carbon stock in the open field for tree type is found in plot 1 with the estimated carbon value of $0.092 \mathrm{ton} / \mathrm{c} / \mathrm{ha}$, for plant type found in plot 2 of 0.158 ton/c/ha with and for litter type encountered in plot 9 of 0.068 ton/c/ha.

The estimation of carbon stock in the land cover type of secondary forest is dominated by Mahang (Macaranga conifera) found with 41 number of trees and have average diameter $17,59 \mathrm{~cm}$ then followed by Medang type (Alseodaphne peduncularis) with the number of trees encountered 34 trees with average diameter $-19.94 \mathrm{~cm}$. For carbon stocks in the plantation are dominated by rubber trees (Hevea brasiliensis) of 72 trees with an average diameter of $19.26 \mathrm{~cm}$ and for carbon stocks in open land cover is dominated by Medang (Alseodaphne peduncularis) found with 5 number of trees with an average diameter of $14 \mathrm{~cm}$ (Table 1). 
Table 1. Dominant trees in Sungai Merah Protection Forest Dominan Trees in Secondary Forest

\begin{tabular}{|c|c|c|c|c|c|c|}
\hline \multirow[t]{2}{*}{ Local Name } & \multirow[t]{2}{*}{ Scientific Name } & \multirow[t]{2}{*}{$\begin{array}{c}\text { Number of } \\
\text { Tree }\end{array}$} & \multicolumn{2}{|c|}{ Biomass (Ton/Ha) } & \multicolumn{2}{|c|}{$\begin{array}{c}\text { Carbon } \\
\text { (Ton/C/Ha) }\end{array}$} \\
\hline & & & Total & Average & Total & Average \\
\hline Mahang & Macaranga conifera & 41 & 5,168 & 0,126 & 2,584 & 0,063 \\
\hline Medang & Alseodaphne peduncularis & 34 & 7,111 & 0,203 & 3,557 & 0,101 \\
\hline Terap & Artacarpus elastica & 21 & 3,684 & 0,175 & 1,842 & 0,087 \\
\hline Kelat & Parastemon urophillum & 14 & 3,305 & 0,157 & 1,652 & 0,078 \\
\hline Putat & Barringtonia scortechinii & 13 & 2,601 & 0,200 & 1,300 & 0,100 \\
\hline Setepung & Dillenia $s p$ & 11 & 2,502 & 0,227 & 1,251 & 0,113 \\
\hline Silok & Gironniera nervosa & 10 & 1,526 & 0,152 & 0,763 & 0,076 \\
\hline Markubung & Macaranga gigan & 9 & 0,651 & 0,093 & 0,325 & 0,046 \\
\hline Bolo & Gynotroches axillaris & 7 & 1,418 & 0,202 & 0,709 & 0,101 \\
\hline Petaling & Ochanostachys amentacea & 6 & 2,128 & 0,354 & 1,064 & 0,177 \\
\hline \multicolumn{7}{|c|}{ Dominant Tree in Plantation } \\
\hline Karet & Hevea brasiliensis & 72 & 17,057 & 0,233 & 8,528 & 0,116 \\
\hline Balik angin & Mallotus paniculatus & 2 & 0,990 & 0,495 & 0,495 & 2,476 \\
\hline Pulai & Alstonia scholaris & 1 & 0,770 & 0,770 & 0,385 & 0,385 \\
\hline Kelat & Parastemon urophillum & 1 & 0,595 & 0,595 & 0,297 & 0,297 \\
\hline \multicolumn{7}{|c|}{ Dominant Tree in Open Land } \\
\hline Jambu eropa & Bellucia pentamera & 1 & 0,185 & 0,185 & 0,092 & 0,092 \\
\hline Leban & Vitex pinnata & 1 & 3,253 & 3,253 & 1,626 & 1,626 \\
\hline Medang & Alseodaphne peduncularis & 5 & 2,517 & 0,503 & 1,258 & 0,251 \\
\hline Mahang & Macaranga conifera & 2 & 0,730 & 0,365 & 0,365 & 0,182 \\
\hline Terap & Artacarpus elastica & 2 & 0,813 & 0,406 & 0,406 & 0,203 \\
\hline Setepung & Dillenia $s p$ & 1 & 0,942 & 0,942 & 0,471 & 0,471 \\
\hline
\end{tabular}

\subsection{Discussion}

The calculations and estimates of carbon stocks show that secondary forest land cover has the largest carbon stock than the other two land cover which is plantation and open land. One of the things that support this situation is that secondary forests have composition of stands or larger diameters and diverse rather than both other land cover.

Other studies produce information or statements that are not different, especially for supporting factors that play a role in determining the range of carbon stock estimation, influenced by the composition of stands, diameter, and diversity of species at a location. Each species has a different contribution to the amount of biomass and reserves of total carbon reserves at a site, the larger the diameter of the stem of the plant, the higher the value of plant biomass, and the longer life of the forest area will contribute to the increase of biomass and forest carbon $[1,7,8,9,10]$.

Data analysis results show that the carbon stock from young vegetation in plantation type was larger than secondary forest land cover. The stand composition causes this situation at the plantation is dominated by young stands with a rare density. This condition gives an effect for the intensity of light that enters through the forest floor, and it has provided better and optimal stand growth that eventually leads to much young vegetation encountered in this land cover type.

The size of the tree canopy diameter and density can obstruct sunlight from being received by plants. So that only a few plants can survive. Light is an energy source for photosynthesis. The length of irradiation has a particular effect on plant growth and reproduction. It is widely found that if the tree stands with high tree density, the tree stands are generally dominated by a small diameter class. Simultaneously, the bigger diameter class was encountered in some locations with less density of trees.

The composition of plant species diversity is influenced by environmental factors such as light, moisture, $\mathrm{pH}$ of the soil, canopy cover from surrounding trees, and the competition level of each species. Stands with older age have a lighter canopy cover so that the young vegetation's get less light, plants need the light for development, growth, and reproduction. states that the litter biomass stocks are directly proportional to standing biomass. The larger the stands biomass, the higher the litter biomass [2].

The estimation of carbon stock values from young vegetation on open land cover type also greater than secondary forest and plantation land cover. In the open land, sunlight can easily enter so that the quality of the place to grow affect the growth of young vegetation. The effect of opening an area by land clearing activities is the intensity of sunlight which penetrates the forest 
floor becomes more [11]. This condition causes the plant's growth and development to grow faster. The estimated value of carbon stocks measured by satellite image interpretation compare with direct measurements is shown in Figure 3.

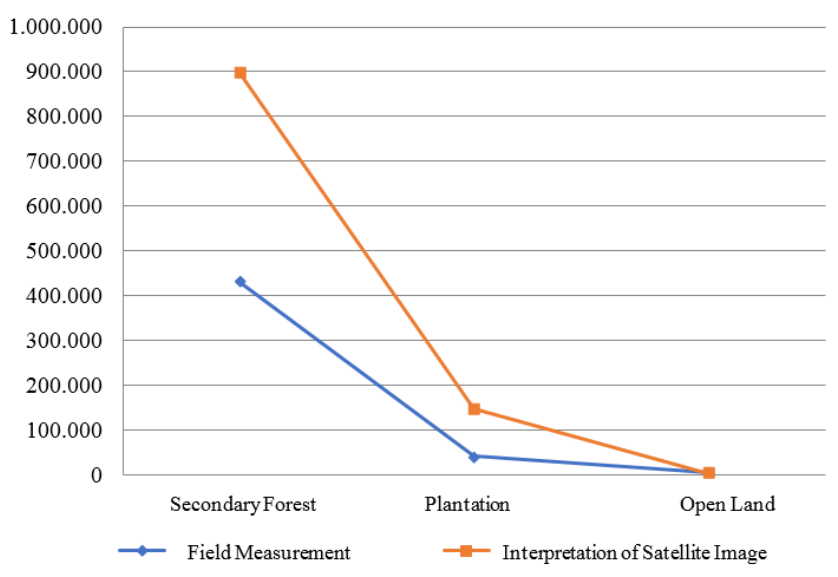

Figure 3. Comparing Result between Interpretation of Satellite Image and Field Measurement

The estimation of carbon stock in HL Sungai Merah estimated through the wide-area calculation from satellite image interpretation is $1,046,221 \mathrm{Ton} / \mathrm{C}$, and the estimation through field calculation is 474,633 Ton/C. Comparing these results indicates that the calculation of carbon stocks through satellite imagery interpretation gives greater results and is significantly different from the estimation through field calculation. The difference between the two methods is $220 \%$.

Carbon calculation in the field certainly takes time, and the cost is relatively high. Carbon calculation by estimating land cover type through satellite imagery interpretation can be an alternative to know carbon stock in the field, although sometimes calculation through this method is often judged to have weaknesses and lack of accuracy. However, the results of the comparison of these two methods can be used as the preliminary reference with a ratio of $220 \%$ to provide information on estimating carbon stocks in secondary forests at a site. The calculation approach that can be done is by the formula:

C. field $=(C$. land cover $) / 220 \times 1 / 100$

where; $\mathrm{C}$. field $=$ the value of carbon stock in the field; C.land cover $=$ the value of carbon stock in land cover.

The estimation of carbon stock obtained based on this research provides preliminary information about the carbon estimation in the Sungai Merah Protection Forest KPHP unit IV Meranti. The availability of carbon stocks in this area can increase as long as the land clearing activities in this area are not done much. According to the field's facts, the protected forest is also utilized by the community as cultivated land. To restore the function of protected forests optimally, as a provider of hydrological and environmental services, FMU managers begin to consider participating in REDD + program mechanisms to maintain the protection forest sustainability and improve the surrounding community's welfare.

\section{Conclusion}

Based on the study, we concluded that carbon stock in Sungai Merah protected forest estimated from satellite image analysis is 1,046,221 tons, and that estimate from field measurements is 474,633 tons. Carbon storage is influenced by the tree's diameter and supported by the number of trees. There is a $220 \%$ difference in carbon stock figures when the two methods were compared. The changes in the carbon inventory values between approaches will provide insight into the progress of measurement.

\section{Acknowledgement}

This work would not have been possible without the financial support of Kementerian Riset, Teknologi dan Pendidikan Tinggi (Ristekdikti) No. 002/SP2H/LT/DRPM/II/2016, also support from staff of Forest Management Unit (KPHP) Meranti, Forest Service of South Sumatra Province.

\section{References}

[1] Dharmawan, I. W. S., \& Samsoedin, I. 2012. Dinamika Potensi Biomassa Karbon Pada Lanskap Hutan Bekas Tebangan di Hutan Penelitian Malinau. Penelitian Sosial Dan Ekonomi Kehutanan, 9(1), 12-20.

[2] Rusdiana, O., \& Lubis, R. S. 2012. Pendugaan Korelasi antara Karakteristik Tanah terhadap Cadangan Karbon ( Carbon Stock ) pada Hutan Sekunder. Silvikultur Tropika, 3(1), 14-21.

[3] Rochmayanti Y., Wibowo A., Lugina M., Butarbutar T., Mulyadin RM., Wicaksono D., 2014. The carbon content in a variety of forest tupes and species plants in Indonesia (seri 2). PT Kanisius, DIY.

[4] Hardjana, A. K. 2015. Kapasitas Stok Biomassa Tegakan Dipterokarpa dan non Dipterokarpa Berdasarkan Kondisi Tutupan Vegetasi Hutan di KHDTK Labanan, Kabupaten Berau, Kalimantan Timur. Prosiding Seminar Nasional Masyarakat Biodiversitas Indonesia, 1(3), 590-596. https://doi.org/10.13057/psnmbi/m010335

[5] Dewi, S. Ekadinata, A. Galudra, G. Agung, P dan Johana, F. 2011. LUWES (Land Use Planning for Low Emission. World Agroforestry Centre, Southeast Asia.

[6] Brown, S. 1997. Estimating biomass and biomass 
change of tropical forest : A primer. FA Forestry Paper 134.

[7] Tiryana, T., Rusolono, T., Siahaan, H., Kunarso, A., Sumantri, H., \& Haasler, B. 2016. Cadangan Karbon Hutan dan Keanekaragaman Flora Di Sumatera Selatan.

[8] Gadut, U., Sumatra, W., Suwardi, A. B., \& Mukhtar, E. 2013. Komposisi Jenis dan Cadangan Karbon di Hutan Tropis Dataran Rendah, Ulu Gadut, Sumatera Barat * [ Species Composition and Carbon Stock in Tropical Lowland Forest ,. Berita Biologi, 12(2), 169-176.

[9] Prasetyo, A., Hikmat, A., \& Prasetyo, L. B. 2011. Pendugaan Perubahan Cadangan Karbon di
Konservasi Alam Tambling Taman Nasional Bukit Barisan Selatan. Media Konservasi, 16(2), 87-91.

[10] Purnomo, D. W. 2015. Peran Kebun Raya Indonesia dalam upaya konservasi tumbuhan dan penurunan emisi karbon. Prosiding Seminar Nasional Masyarakat Biodiversitas Indonesia, l(Smith 2005), 66-70. https://doi.org/10.13057/psnmbi/m010110

[11] Junaedi, A. 2014. Estimasi Jumlah Karbon Vegetasi yang Hilang Akibat Kegiatan Pemanenan Kayu di Hutan Alam Tropis. Hutan Tropis, 2(2), 146-151. 